\title{
Eight Small-red Dry Bean Germplasm Lines with Upright Architecture, Narrow Profile, and Short Vine Growth Habit
}

\author{
George L. Hosfield
}

Sugar-beet and Bean Research Unit, U.S. Department of Agriculture, Agricultural Research Service, and Crop and Soil Sciences Department, Michigan State University, East Lansing, MI 48824

James D. Kelly ${ }^{2}$ Crop and Soil Sciences Department, Michigan State University, East Lansing, MI 48824

\section{M.J. Silbernagel ${ }^{3}$}

Vegetable and Forage Crops Production Research, U.S. Department of Agriculture, Agricultural Research Service, Prosser, WA 99350

\section{J.R. Stavely ${ }^{3}$}

Molecular Plant Pathology Laboratory, U.S. Department of Agriculture, Agricultural Research Service, Beltsville, MD 20705

M.W. Adams ${ }^{4}$

Crop and Soil Sciences Department, Michigan State University, East Lansing, MI 48824

\section{M.A. Uebersax ${ }^{2}$}

Department of Food Science and Human Nutrition, Michigan State University, East Lansing, MI 48824

\section{G.V. Varner}

Michigan Dry Bean Production Research and Advisory Board, 3066 South Thomas Road, Saginaw, MI 48603

Additional index words. Phaseolus vulgaris, Uromyces appendiculatus, bean common mosaic virus, anthracnose, culinary quality, plant breeding

Eight germplasm lines of dry bean (Phaseolus vulgaris L.) were developed by the U.S. Dept. of Agriculture, Agricultural Research Service, and the Michigan Agricultural Expt. Station. They were approved for release in 1995 as lines that combine an upright and narrow profile and short vine growth habit with desirable seed size, shape, and pigmentation of the small-red (formerly

Received for publication 10 Dec. 1994. Accepted for publication 8 Aug. 1995. Research supported by U.S. Dept. of Agriculture (USDA), Agricultural Research Service, and the Michigan Agricultural Expt. Station. Names are necessary to report factually on available data; however, the USDA neither guarantees nor warrants the standard of the product, and the use of the name by USDA implies no approval of the product to the exclusion of others that may also be suitable. The cost of publishing this paper was defrayed in part by the payment of page charges. Under postal regulations, this paper therefore must be hereby marked advertisement solely to indicate this fact.

'Research Geneticist.

${ }^{2}$ Professor.

${ }^{3}$ Research Plant Pathologist.

${ }^{4}$ Retired, Professor Emeritus.

${ }^{5}$ Agronomist.
Centro Internacional de Agricultura Tropical (CIAT), Cali, Colombia (Singh, 1982). CIAT recognizes four growth habits: Type I, II, III, and IV. Indeterminate plants that are upright with short vines are representative of the Type IIa growth habit (Singh, 1982). The lines ARS-R93001, -R93002, -R93003, -R93004, -R93005, -R93006, -R93007, and -R93008 are the first released small-red beans with an erect Type IIa growth habit, compared to Type IIb (terminal guide of varying length and climbing ability) and the prostrate indeterminate vine Type III habit of commercial cultivars. The Type IIa indeterminate plant habit in $P$. vulgaris is associated with high yield potential and yield stability in the navy bean and the tropical black-bean market classes in the midwestem U.S. bean production areas (Kelly and Adams, 1987). In contrast to Type II cultivars, cultivars with the Type III growth habit are at a significantly higher risk of losing production to diseases and weather damage under humid conditions. Many pods of commercial small-red cultivars touch the ground. This feature increases the risk of harvest loss and poor seed quality in wet weather (Kelly and Adams, 1987). Moreover, the prostrate vine habit, with its dense plant canopy often causes a microclimate to develop that favors white mold [ Sclerotinia sclerotiorum (Lib.) de Bary] disease infection. Blad et al. (1978) found the highest severity of white mold associated with the dense plant canopy of beans with a prostrate growth habit, compared to a more upright and open plant canopy.

\section{Origin}

ARS-R93001 to ARS-R93008 are $\mathrm{F}_{2}$ derived $\mathrm{F}_{9}$ germplasm lines. Lines ARSR93001 to ARS-93006 originated from the following respective crosses between Michigan State Univ. (MSU) accessions: X885 13/ X88401, X88513/X88403, X88513/X88404, X885131X88408, X88514/X88407, and

X88517/X88401. The parental accessions accepted growth habit classification in $P$. vulgaris is according to the system of the

Table 1. Mean yield, seed weights, and maturity of eight small-red market-class dry bean germplasm lines and two commercial cultivars (controls) in tests from 1991 to $1994 .^{2 .}$

\begin{tabular}{lcccc}
\hline \hline & $\begin{array}{c}\text { Yield } \\
\left(\mathrm{kg} \bullet \mathrm{ha}^{-1}\right)^{\mathrm{x}}\end{array}$ & $\begin{array}{c}\text { Seed wt } \\
(\mathrm{g} / 100 \mathrm{seed})\end{array}$ & $\begin{array}{c}\text { Time to } \\
\text { maturity } \\
\text { (days) }\end{array}$ & $\begin{array}{c}\text { No. tests/ } \\
\text { entry }\end{array}$ \\
\hline ARSR93001 & 2306 & 38.6 & 85 & 6 \\
ARS-R93002 & 2256 & 35.0 & 83 & 6 \\
ARSR93003 & 2314 & 37.2 & 83 & 6 \\
ARSR93004 & 2163 & 39.7 & 85 & 5 \\
ARS-R93005 & 2250 & 32.7 & 80 & 8 \\
ARSR93006 & 2274 & 40.1 & 82 & 7 \\
ARSR93007 & 2073 & 34.2 & 82 & 7 \\
ARSR93008 & 2086 & 36.1 & 76 & 8 \\
Rufus, control" & 2755 & 32.7 & 84 & 8 \\
Garnet, control" & 2200 & 27.2 & 78 & 5 \\
Entry mean, including controls $^{v}$ & 2268 & 55.3 & 82 & $\mathrm{NA}^{\mathrm{u}}$ \\
Entry mean, without controls $^{\mathrm{v}}$ & 2215 & 36.7 & $\mathrm{~N} \mathrm{~A}^{\mathrm{u}}$
\end{tabular}

${ }^{2}$ Statistical analyses of data combined over tests was not feasible.

'Eight tests were conducted from 1991 to 1994 as follows: 1991: 42 entry, three replications (reps) in Saginaw, Mich.; 1992: 15 entry, four reps in Saginaw, Mich., and 12 entry, four reps at Bay Co., Mich.; 1993: 42 entry, three reps and 81 entry, three reps in Saginaw, Mich., and 10 entry, four reps at Aranac Co., Mich., and 12 entry, four reps at Sanilac Co., Mich.; and 1994: 56 entry, three reps in Saginaw, Mich.

${ }^{x}$ Yield adjusted to $18 \%$ moisture equivalent.

"'Rufus' and 'Garnet' are experimental controls.

"Grand mean.

"Not applicable. 
X88513, X88514, and X88517 were derived from crosses between MSU breeding lines with small-red market-class seed characteristics and pinto breeding lines with an upright architecture and Type IIa growth habit. The upright and Type II pinto breeding lines were derived from a series of recurrent crosses, initiated in 1980, using nine commercial pinto bean cultivars and 16 small-seeded and upright navy and black-bean breeding lines (Kelly and Adams, 1987).

The parents X88401, X88403, X88404, X88407, and X88408 were developed by the Michigan Agricultural Expt. Station. The accession X88401 was an adapted breeding line selected from a cross between P86297 and UI36, a commercial small-red cultivar. Line P86297 is an upright architecture Type-II growth habit pinto bean that is a full-sib of 'Sierra' pinto bean and constitutes $50 \%$ of the germplasm in 'Aztec' pinto bean and $50 \%$ of the germplasm in 'Alpine' great northern bean.

The accessions X88403 and X88404 were full-sib selections from a complex cross, involving six parents, in which the last cross was made to the small-red cultivar Ember (Rogers Seed Co., Nampa, Idaho). The parent X88407 resulted from a cross between 'Ember' and XPB 197, a red-seeded breeding line obtained from the Asgrow Seed Co., Twin Falls, Idaho. The X88408 parent was a three-way cross produced by crossing P86297 by 'Desarrural', a red-seeded Central American cultivar, and then subsequently crossing an $\mathrm{F}_{2}$ selection from this cross by 'Ember'.
The lines ARS-R93007 and ARS-R93008 are full-sib selections from the three-way cross, X88403 × 'Revolution-79' × P86297. 'Revolution-79' is a cultivar with small, red seeds ( 25 to $28 \mathrm{~g} / 100$ seed) released in Nicaragua.

Initial selections of the eight new germplasm lines were based on an individual $\mathrm{F}_{2}$ plant possessing upright architecture and the preferred seed type. Each $\mathrm{F}_{2}$ plant was advanced as an $\mathrm{F}_{2}$ plant row in Puerto Rico. In Michigan, a single $\mathrm{F}_{2}$ plant row underwent a restricted form of mass-selection; only four to 10 plants (select bulk) were selected per row based on similarity in seed characteristics and upright architecture. Seeds from each selection were bulked and advanced in $\mathrm{F}_{5}$ rows in Puerto Rico and mass-selected. The $\mathrm{F}_{6}$ generation entered yield trials in Michigan. Plants from remnant seed were screened for reaction to Uromyces appendiculatus (Pers.:Pers.) Unger, the cause of bean rust, and screened for bean common mosaic virus (BCMV).

\section{Description and performance}

Comparisons for yield, agronomic characteristics, and culinary quality were made between the eight new small-red germplasm lines and the controls 'Rufus' and 'Garnet' (Tables 1 and 2). 'Rufus' and 'Garnet' are commercially grown small-red cultivars possessing a Type III prostrate growth habit characteristic of most commercial cultivars of this market class. 'Rufus' was tested for 4 years in
Michigan (1991 to 1994) and produced 2755 $\mathrm{kg} \bullet \mathrm{ha}^{-1}$ and matured in 84 days on average. 'Garnet' yielded $2200 \mathrm{~kg} \bullet \mathrm{ha}^{-1}$, was 6 days earlier, and had smaller seeds ( 27 vs. $33 \mathrm{~g} / 100$ seeds) than 'Rufus' (Table 1). Both cultivars have acceptable culinary quality (Table 2 ).

The eight small-red germplasm lines were tested for yield at five to eight locations over 4 years (1991 to 1994). The yield of the lines was $80 \%$ of that for 'Rufus' but was similar to that for 'Garnet' (Table 1). ARS-R93003 was the highest-yielding line, while ARS-R93007 was the lowest.

All the germplasm lines, except ARS-93005, had heavier seed than 'Rufus' or 'Garnet' and ranged from $33 \mathrm{~g} / 100$ seeds (ARS-R93005) to $40 \mathrm{~g} / 100$ seeds (ARS-R93006) (Table 1). ARS-93005 and 'Rufus' had similar seed weights. The heavier seed of the new germ plasm lines would enhance the export potential of the small-red market class, particularly to East Africa, where red bean seeds at $\approx 40.0$ g/100 seeds are preferred by consumers, and to the Caribbean region.

Plant architectures of the eight new lines resemble the ideotype for dry bean production under monoculture proposed by Adams ( 1973). Plants of these lines have a strong main stem with three to five basal branches acutely angled upward (Fig. 1).

Plants of the eight germplasm lines ranged from 39 to $55 \mathrm{~cm}$ tall and averaged 82 days to maturity, with a range of 76 (ARS-R93008) to 85 (ARS-R93001 and ARS-R93004)days. All the new lines had excellent resistance to lodg-

Table 2. Means for soaking and processing traits of eight small-red market-class dry bean germplasm lines and two commercial cultivars (controls) in tests from 1991 to 1994.

\begin{tabular}{|c|c|c|c|c|c|c|c|c|}
\hline \multirow[b]{3}{*}{ Entry } & \multicolumn{2}{|c|}{ Mass ratios $^{x}$} & & & & \multirow[b]{3}{*}{$\begin{array}{l}\text { Shear force } \\
(\mathrm{N} / 100 \mathrm{~g})\end{array}$} & \multirow[b]{3}{*}{$\mathrm{PQI}^{\prime}$} & \multirow[b]{3}{*}{ No./entry } \\
\hline & \multirow[b]{2}{*}{$\begin{array}{l}\text { Hydration } \\
\text { coefficient }\end{array}$} & \multirow{2}{*}{$\begin{array}{l}\text { Washed- } \\
\text { drained } \\
\text { coefficient }\end{array}$} & \multicolumn{3}{|c|}{ Processed bean color } & & & \\
\hline & & & $\begin{array}{l}\mathrm{Hu} \mathrm{e}^{\mathrm{w}} \\
\text { (degree) }\end{array}$ & $\begin{array}{l}\text { Chroma }^{v} \\
\text { (units) }\end{array}$ & $\begin{array}{l}\text { Lightness" } \\
\text { (units) }\end{array}$ & & & \\
\hline ARS-R93001 & 1.9 & 1.3 & 40.3 & 25.8 & 27.1 & 8.2 & 27.4 & 5 \\
\hline ARS-R93002 & 1.8 & 1.3 & 40.4 & 25.2 & 27.6 & 9.1 & 28.5 & 5 \\
\hline ARS-R93003 & 1.8 & 1.4 & 41.0 & 25.2 & 26.6 & 7.9 & 27.3 & 5 \\
\hline ARS-R93004 & 1.8 & 1.3 & 40.8 & 25.4 & 28.8 & 9.5 & 28.8 & 4 \\
\hline ARS-R93005 & 1.8 & 1.3 & 39.4 & 25.1 & 25.9 & 7.7 & 28.6 & 5 \\
\hline ARS-R93006 & 1.8 & 1.4 & 40.3 & 25.3 & 26.6 & 7.3 & 28.9 & 4 \\
\hline ARS-R93007 & 1.8 & 1.3 & 38.7 & 24.9 & 25.7 & 7.7 & 28.7 & 4 \\
\hline ARS-R93008 & 1.7 & 1.4 & 39.0 & 24.6 & 24.8 & 8.4 & 31.2 & 5 \\
\hline Rufus, control ${ }^{s}$ & 1.8 & 1.3 & 39.3 & 24.3 & 26.0 & 8.8 & 28.0 & 5 \\
\hline Garnet, control ${ }^{\mathrm{s}}$ & 1.8 & 1.3 & 38.7 & 25.1 & 24.4 & 8.1 & 27.2 & 5 \\
\hline $\begin{array}{l}\text { Entry mean, } \\
\text { including controls' }\end{array}$ & 1.8 & 1.3 & 39.8 & 25.1 & 26.3 & 8.3 & 28.5 & $\mathrm{NA}^{\mathrm{q}}$ \\
\hline $\begin{array}{l}\text { Entry mean, } \\
\text { without controls' }\end{array}$ & 1.8 & 1.3 & 40.0 & 25.2 & 26.6 & 8.2 & 28.7 & $\mathrm{NA}^{\mathrm{q}}$ \\
\hline
\end{tabular}

${ }^{2}$ Statistical analyses of data combined over tests was not feasible.

'Eight tests were conducted at Saginaw, Mich., from 1991 to 1994 as follows: 1991: 42 entry, three replications (reps); 1992 : 15 entry, 4 reps; 1993 : 42 entry, three reps and 81 entry, three reps; and 1994: 56 entry, three reps.

${ }^{x}$ Hydration coefficient $=$ soaked bean weight $($ grams $) /$ fresh weight $($ grams $)$ to yield $100 \mathrm{~g}$ solids; washeddrained coefficient $=$ washed-drained weight $($ grams $) /$ soaked bean weight (grams).

${ }^{\text {w}}$ Hue angle $=$ takes into account the red to green and yellow to blue scale of a color and color difference meter and is an expression of human perception of the yellowness or redness of a sample.

"Chroma = an expression of color saturation of a sample, measured on a color and color difference meter, and the degree of redness, greenness, yellowness, and blueness, according to the Commission Internationale de el Eclairage (1976).

"Lightness = Commission Internationale de el Eclairage (1976) psychometric lightness.

'PQI = processing quality index, constructed as a linear function of the following descriptors: the amount of clumping, splitting, and overall appearance of canned beans; cooking broth characteristics of viscosity, color, and the amount of starch exudation; and cooked seed characteristics of color, size, and shape for the market class.

'Rufus' and 'Garnet' are experimental controls.

'grand mean.

${ }^{9}$ Not applicable. 
ing (data not shown) compared to 'Rufus' and 'Garnet'

Line ARS-R93002 is heterogeneous for the $U r-3$ rust resistance gene. Plants carrying the $U r-3$ gene are highly resistant to race 53 and all indigenous rust races prevalent in Michigan. Germplasm lines ARS-R93006, -R93007, and -R93008 carry the single dominant hypersensitive I gene resistance to BCMV combined with the recessive $b c-1^{2}$ gene. Plants carrying only the $I$ gene for resistance are subject to the sometimes lethal hypersensitive reaction, a systemic vascular necrosis syndrome, which is prevented by the presence of strain-specific recessive genes. The recessive $b c-1^{2}$ resistance gene in combination with the dominant $I$ gene protects plants against lethal systemic necrosis caused by the NL3 strain of the virus. All germplasm lines are susceptible to bean anthracnose caused by Colletotrichum lindemuthianum [(Sacc. \& Magnus)Lams:Scrib.].

The eight lines were tested for their aggregate culinary qualities (Table 2) reflecting preferences and requirements for the dry and cooked grains (Hosfield and Uebersax, 1980; Hosfield et al., 1984). Culinary quality was evaluated subjectively (using a team of trained judges) and objectively (using instruments and gravimetric procedures). The subjective evaluation of quality was based on a processing quality index (PQI) that was constructed as a linear function of the following descriptors: the amount of clumping, splitting, and overall appearance of canned beans; cooking broth characteristics of viscosity, color, and the amount of extruded starch; and cooked seed characteristics of color, size, and shape for the market class. Index values reported herein are the averages for five judges over 4 years of testing. Higher PQI values indicate better quality. The PQIs of the eight lines were all acceptable and ranged from 27.3 to 31.2 for the eight germplasm lines, with ARS-R93004, ARSR93006, and ARS-R93008 having superior values (Table 2). All of the lines had PQIs more than 'Garnet'.

Data taken on soaked and processed bean soakability was expressed in terms of the mass ratios: hydration ratio and washed-drained weight ratio. The hydration ratio trait reflects the weight increase of beans after soaking due to water absorption relative to the initial fresh weight; a value of 1.8 is optimum for a sample of well-hydrated beans. The washed-drained weight ratio is an indicator of water entrainment after bean processing. Beans with washed-drained weight ratios of 1.5 have optimum water entrainments. The mean hydration ratios of the eight small-red germplasm lines was 1.8 , the same as for 'Rufus' and 'Garnet' (Table 2). The washed-drained weight ratios of the eight germplasm lines averaged 1.3 and were equivalent to those for 'Rufus' and 'Garnet' (Table 2).

The surface color of seeds, an important consumer and processor quality characteristic, was measured on the $\mathrm{L}, \mathrm{a}_{\mathrm{L}}$, and $\mathrm{b}_{\mathrm{L}}$ scales of a color and color difference meter (Hunter Associates, Reston, Va.) (Uebersax and Hosfield, 1979). All the germplasms had dry

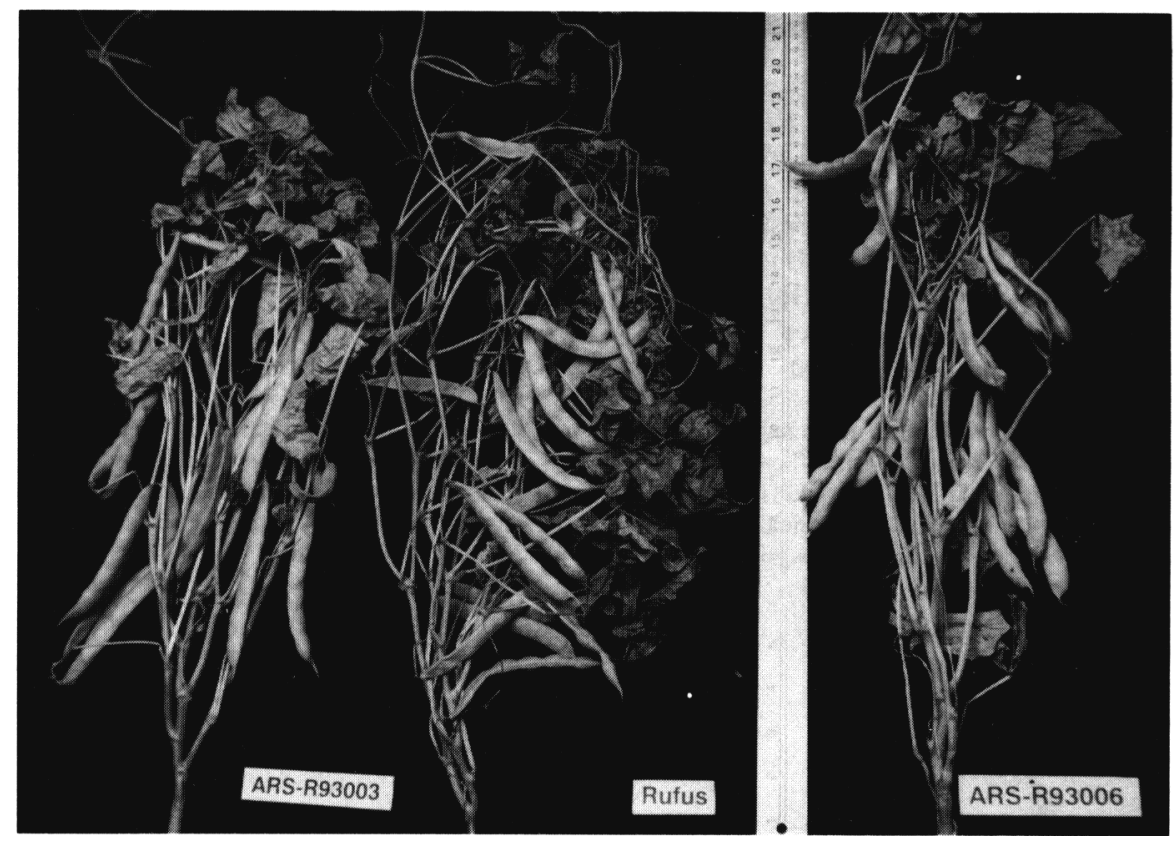

Fig. 1. Comparison of selected U.S. Dept. of Agriculture, Agricultural Research Service, small-red germplasm lines with the commercial cultivar Rufus. Note the strong branching and erect architecture of the new germplasm lines vs. the weak plant structure of 'Rufus'.

and processed surface color readings within the acceptable range for dry and processed small-red beans. However, as indicated by their L values, the lines ARS-93002, -93004, and -93006 had brighter dry $(31.3,30.5$, and 30.0 , respectively) seed than 'Rufus' (27.2) or 'Garnet' (26.9). On the Hunter L scale, a value of 100 indicates a pure-white object, and a value of 0 indicates a black object. The dry seed L value for ARS-93001, -93003, -93005, and -93007 indicated they were darker than 'Rufus' or 'Garnet' (data not shown). The line ARS-R93008 had an L value of 27.0.

The $L, a_{L}$, and $b_{L}$ characteristics of the Hunter Lab color and color difference meter were converted to Munsell color system dimensions of lightness, hue angle, and chroma to make the color attributes of the beans more relevant to human perception (Table 2).

The cooked bean lightness scores of ARS-R93001, -R93002, -R93003, -R93004, and -R93006 indicated that they were brighter than either 'Rufus' or 'Garnet' (Table 2). The lines ARS-R93005, -R93007, and -R93008 had slightly darker cooked beans than 'Rufus', but were slightly brighter than 'Garnet'

On average, the eight new germplasm lines had higher hue angles for processed beans ( $\mathrm{X}$ $=40.0$ ") than 'Rufus' or 'Garnet'. Hue angle takes into account the $a$, (red to green) and $b_{L}$ (yellow to blue) scale of the Hunter Lab color and color difference meter and is an expression of human perception of the yellowness or redness of a sample. A hue angle close to $90^{\circ}$ indicates an increase in yellowness, while the farther away it is from $90^{\circ}$ indicates an increased redness (Ruengsakulrach et al., 1994). The hue angles of the eight germplasm lines indicated that they were more intensely red than 'Rufus' or 'Garnet'.

Chroma values of the eight germplasm lines ranged from 24.6 (ARS-R93008) to 25.8
(ARS-R93001), and the data (Table 2) indicate that the intensity of the red for the lines was greater than for 'Rufus'. When the germplasm lines were compared to 'Garnet', ARSR93005, -R93007, and -R93008 had chroma values equal to or lower than this varietal control (Table 2). The chroma value of a sample indicates color saturation, describes reflection at a given wavelength, and shows how much a color differs from a gray of the same lightness (i.e., the intensity of the color or the amount of pigment of the sample) (Chung et al., 1995).

Forces required to bring a bean to a point of rupture and catastrophic breakdown were determined with a Kramer shear press, which simultaneously estimates the kinesthetic properties of food, namely hardness, gumminess, and adhesiveness. Resistance of the eight germplasm lines ranged between 7.3 and $9.5 \mathrm{~N} /$ $100 \mathrm{~g}$ (Table 2). ARS-R93006 was within the superior range of 6.5 to $7.5 \mathrm{~N} / 100 \mathrm{~g}$ established for processed small-red beans, while the remaining lines, except for ARS-R93004 and ARS-R93002, were within the acceptable range of 5.5 to $8.5 \mathrm{~N} / 100 \mathrm{~g}$. At $9.5 \mathrm{~N} / 100 \mathrm{~g}$, ARS-R93004 was considered a firm bean. Kramer shear press forces for 'Garnet' and 'Rufus' were >8.0 N/100 g.

The new germplasm lines with their upright and erect plant structure represent a significant improvement in the adaptation of small-red beans for the humid Great Lakes region of the American Midwest and likely will be valuable as parental lines in bean breeding programs. Using upright pinto beans as a genetic bridge offers the best opportunity to improve the architecture of bean germplasm in the small-red market class because naturally occurring medium-seeded (30 to 40 g/100 seed) genotypes with Type II growth habit are rare (Brothers and Kelly, 1993). 


\section{Availability}

A limited quantity of seed is available from G.L.H., Sugarbeet and Bean Research Unit, U.S. Dept. of Agriculture, Agricultural Research Service, Dept. of Crop and Soil Sciences, Michigan State Univ., East Lansing, MI 48824. The Michigan Agricultural Expt. Station has no seed of these lines for distribution.

\section{Literature Cited}

Adams, M.W. 1973. Plant architecture and physiological efficiency in the field bean, p. 266-278. In: Seminar on potential of field bean and other food legumes in Latin America. Seminar Ser 2E. Centro Internacional de Agriculutra Tropical, Cali, Colombia.
Blad, B.L., J.R. Steadman, and A. Weiss. 1978 Canopy structure and irrigation influence white mold disease and microclimate of dry edible beans. Phytopathology 68: 1431-1437.

Brothers, M.E. and J.D. Kelly. 1993. Interrelationship of plant architecture and yield components in the pinto bean ideotype. Crop Sci. 33:1234 1238.

Chung, Y.S., J.C. Jackson, M.A. Uebersax, J.D. Kelly, and R.A. Long. 1995. Evaluation of color and selected physical characteristics of kidney beans grown in northern Michigan. Mich. Dry Bean Dig. 19(3):15-19.

Hosfield, G.L., A. Ghaderi, and M.A. Uebersax. 1984. A factor analysis of yield and sensory and physico-chemical data from tests used to measure culinary quality in dry edible beans. Can. J. Plant Sci. 64:285-293.

Hosfield, G.L. and M.A. Uebersax. 1980. Variabil- ity in physico-chemical properties and nutritional components of tropical and domestic dry bean germplasm. J. Amer. Soc. Hort. Sci. 105:246-252.

Kelly, J.D. and M.W. Adams. 1987. Phenotypic recurrent selection in ideotype breeding of pinto beans. Euphytica 36:69-80.

Ruengsakulrach, S., N. Srisuma, M.A. Uebersax, G.L. Hosfield, and L.G. Occeña. 1994. Early generation screening of navy bean breeding lines by canning quality assessment and pasting characteristics of bean flour. J. Food Qual. 17:321-333.

Singh, S.P. 1982. A key for identification of different growth habits of Phaseolus vulgaris L. Annu. Rpt. Bean Improvement Coop. 25:92-94.

Uebersax, M.A. and G.L. Hosfield. 1979. Evaluation of the surface color of dry edible beans. HortScience 14:469. 